\title{
Generation of pyroclastic flows by explosive interaction of lava flows with ice/water-saturated substrate
}

\author{
Alexander Belousov $^{\mathrm{a}, *}$, Boris Behncke ${ }^{\mathrm{b}}$, Marina Belousova ${ }^{\mathrm{a}, \mathrm{c}}$ \\ a Earth Observatory of Singapore, Nanyang Technological University, Singapore \\ ${ }^{\mathrm{b}}$ Istituto Nazionale di Geofisica e Vulcanologia, Sezione di Catania, Italy \\ c Institute of Volcanology and Seismology, Petropavlovsk, Russia
}

\section{A R T I C L E I N F O}

\section{Article history:}

Received 6 May 2010

Accepted 8 January 2011

Available online 19 January 2011

\section{Keywords:}

lava flow

pyroclastic flow

secondary explosion

phreatomagmatic explosion

Klyuchevskoy

Etna

\begin{abstract}
A B S T R A C T
We describe a new type of secondary rootless phreatomagmatic explosions observed at active lava flows at volcanoes Klyuchevskoy (Russia) and Etna (Italy). The explosions occurred at considerable (up to $5 \mathrm{~km}$ ) distances from primary volcanic vents, generally at steep $\left(15-35^{\circ}\right)$ slopes, and in places where incandescent basaltic or basaltic-andesitic lava propagated over ice/water-saturated substrate. The explosions produced high (up to $7 \mathrm{~km}$ ) vertical ash/steam-laden clouds as well as pyroclastic flows that traveled up to $2 \mathrm{~km}$ downslope. Individual lobes of the pyroclastic flow deposits were up to $2 \mathrm{~m}$ thick, had steep lateral margins, and were composed of angular to subrounded bomb-size clasts in a poorly sorted ash-lapilli matrix. Character of the juvenile rock clasts in the pyroclastic flows (poorly vesiculated with chilled and fractured cauliflower outer surfaces) indicated their origin by explosive fragmentation of lava due to contact with external water. Non-juvenile rocks derived from the substrate of the lava flows comprised up to $75 \%$ in some of the pyroclastic flow deposits. We suggest a model where gradual heating of a water-saturated substrate under the advancing lava flow elevates pore pressure and thus reduces basal friction (in the case of frozen substrate water is initially formed by thawing of the substrate along the contact with lava). On steep slope this leads to gravitational instability and sliding of a part of the active lava flow and water-saturated substrate. The sliding lava and substrate disintegrate and intermix, triggering explosive "fuel-coolant" type interaction that produces large volume of fine-grained clastic material. Relatively cold steam-laden cloud of the phreatomagmatic explosion has limited capacity to transport upward the produced clastic material, thus part of it descends downslope in the form of pyroclastic flow. Similar explosive events were described for active lava flows of Llaima (Chile), Pavlof (Alaska), and Hekla (Iceland) indicating that this type of explosions and related hazard is common at snow/ice-clad volcanoes and sometimes happens also on fluid-saturated hydrothermally altered slopes.
\end{abstract}

(c) 2011 Elsevier B.V. All rights reserved.

\section{Introduction}

Secondary rootless phreatomagmatic explosions occur in settings where subaerial lava flows come into contact with surface water bodies, wet ground, snow or ice (e.g. Fisher and Schmincke, 1984; Morrissey et al., 2000). They were described for lava flows on Hawaii (Mattox and Mangan, 1997), Kamchatka (Vinogradov and Muravyev, 1985; Belousov, 1990, 1996), Iceland (Morrissey and Thordarson, 1991; Hamilton et al., 2010), and Italy (Behncke et al., 2008). Secondary explosions typically represent rather mild vertical ejections of steam containing some amount of fragmented lava. It is believed that they pose fewer hazards than primary explosive activity of the same eruption and/or the parental lava flow itself. As a result

\footnotetext{
* Corresponding author at: Earth Observatory of Singapore, Nanyang Technological University, N2-01a-15, 50 Nanyang Avenue, 639798, Singapore. Tel.: +65 65921827.

E-mail address: abelousov@ntu.edu.sg (A. Belousov).
}

secondary explosions and their products have received relatively little attention and study until now. At the same time secondary explosions are difficult to predict, and they pose serious danger for people attracted by scenic view of "safe" effusive eruptions (Lockwood and Hazlett, 2010). Thus understanding the mechanisms of secondary explosions is important.

Two mechanisms of secondary phreatomagmatic explosions have been suggested by previous researchers: explosion of "pressurized bowl" (e.g. Vinogradov et al., 1987) and the so-called Molten Fuel Coolant Interaction (MFCI) (e.g. Morrissey et al., 2000). In the first case water boils under an advancing lava flow and forms a pocket of pressurized steam that explodes when the pressure of steam exceeds the lithohydrostatic pressure of the overlying lava. In the second case explosion occurs when water and lava explosively interact due to surface instability between water and melt. This latter process has been investigated in detail in experimental works (Wohletz, 1983; Zimanowski, 1998; White and Houghton, 2000; Zimanowski and Wohletz, 2000). 
Most of the secondary phreatomagmatic explosions are rather weak in comparison with primary phreatomagmatic explosions occurring in confined conditions of volcanic conduits. In the case of the "pressurized bowl" mechanism, low magnitude of secondary explosions is probably associated with relatively low confining pressure under advancing lava flows. The pressure is limited by thicknesses of lava flows (commonly $<10 \mathrm{~m}$ ) providing a confining pressure of less than 3 bars. MFCI between lava flows and surface water bodies is limited because extremely different material properties (e.g. high viscosity of lava) hinder hydrodynamic intermixing processes in unconfined conditions (Zimanowski and Wohletz, 2000). This explains why in some cases lava can flow across wet terrain or enter surface water body without notable explosive activity.

The existing literature describes products of secondary phreatomagmatic explosions at lava flows as ballistics and ash fallout deposits (e.g. Mattox and Mangan, 1997; Hamilton et al., 2010). Ballistics of repeating secondary explosions form small cones called littoral cones or pseudocraters (Morrissey et al., 2000). Commonly these products have higher clast density than products simultaneously erupted from the primary vent (Lockwood and Hazlett, 2010). Presence of high percentage of fine-grained particles having surface features that result from melt fragmentation in brittle mode (blocky morphology with chip-off marks) is an evidence of an MFCI type of explosion (Büttner et al., 2002). Although some of those secondary explosions produced weak base surges, no evidence for pyroclastic flows able to travel several kilometers from the source has been described until now.

In this paper we present results of detailed direct observations as well as investigations of eruption products of unusually powerful secondary phreatomagmatic explosions on lava flows of Klyuchevskoy (Kamchatka) and Etna (Sicily). Specific feature of these explosions was the generation of significant pyroclastic flows that notably increased the hazardous areas from the respective eruptions. We also consider cases of supposedly similar events during eruptions of Llaima (Chile), Pavlof (Alaska), and Hekla (Iceland). The obtained data allow us to suggest a mechanism of the observed explosions.

\section{Klyuchevskoy volcano}

\subsection{Eruptions of Klyuchevskoy volcano}

Klyuchevskoy, Kamchatka Peninsula, Russia (summit elevation fluctuating between 4750 and $4800 \mathrm{~m}$ above sea level [masl] due to frequent eruptions) is one of the most active volcanoes in the world with an average magma discharge rate of $6 \times 10^{7} \mathrm{t} / \mathrm{year}$ (Piip, 1956; Manen and Dehn, 2009). The volcano is very young, with an age of approximately 7000 years (Braitseva et al., 1995). Since the beginning of the historical period (1697 in the region) more than 80 eruptions have been recorded (Fedotov and Masurenkov, 1991). The activity of Klyuchevskoy volcano in general is similar to that of Etna, consisting of both summit and flank eruptions. The mechanism of the eruptions is mostly magmatic; there is no evidence that water/magma interaction in the conduit and/or vent area plays a notable role in magma fragmentation. Most of the eruptions are moderate $(\mathrm{VEI}<3$ ) Strombolian including the formation of cinder cones and effusion of rather viscous (2-10 $\mathrm{m}$ thick) blocky lava flows. The Strombolian activity is sometimes punctuated by short-lived weak-to-mild explosions with formation of vertical dark ash-laden clouds similar to the Vulcanian activity.

Summit eruptions are most frequent - they occur almost every year, being separated by repose periods lasting from several months to a few years (Piip, 1956). Summit eruptions commonly last several days to several months, but sometimes continue for years. The most vigorous stages of some of the strongest summit eruptions include short periods (several hours long) of subplinian activity (VEI 3-4), with eruption columns rising $7-12 \mathrm{~km}$ above the summit. There are 10 documented cases of such climactic summit eruptions in historical time, the latest in 1945 and 1994 (Piip, 1956; Ozerov et al., 1997). Lava flows of summit eruptions descend down to elevations of approximately 2500 masl, reaching lengths of $5 \mathrm{~km}$.

Flank eruptions are less frequent; fifteen eruptions have been reported in historical time at elevations ranging from 500 to 4600 masl. These eruptions are characterized by the opening of radial fissures on the slope of the volcano, along which several cinder cones are formed in the process of Strombolian activity accompanied by lava effusion. Some flank eruptions (e.g. 1980 and 1988) were almost purely effusive. Lava flow lengths range from a few hundred meters to $11 \mathrm{~km}$ (the 1966 flank eruption).

The magmas erupted by Klyuchevskoy have basaltic to basaltic andesite compositions (calc-alkaline with two varieties: high magnesium and high alumina) with surface temperatures of up to $1100{ }^{\circ} \mathrm{C}$ (Ozerov, 2000). High alumina magmas are typical for summit eruptions, while both types are observed in the products of flank eruptions. Volumes of magma erupted through summit crater are in the range of $10^{7} \mathrm{~m}^{3}$, whereas flank eruptions produce up to several $10^{8} \mathrm{~m}^{3}$, the latter comprising mostly lava flows (Fedotov and Masurenkov, 1991).

\subsection{Conditions on slopes of the volcano}

Slopes of the volcano are up to $35-40^{\circ}$ in the upper part of the cone and $20^{\circ}$ and less in their lower part. The high elevation (4750$4800 \mathrm{~m}$ ) and a rather cold (55 latitude) and humid climate of the area result in the accumulation of thick snow pack at Klyuchevskoy volcano during winters (lasting 8 months/year). By the onset of spring a thickness of tightly wind-packed snow commonly reaches $2 \mathrm{~m}$ in elevated areas and up to $8 \mathrm{~m}$ in ravines. The average accumulation of snow at high elevations is about $1000-2000 \mathrm{~mm}$ of water equivalent (Muravyev, 1985). Part of the accumulated snow has not enough time to melt during the short summer period and thus forms multiple permanent snowfields at elevations higher than 1000 masl.

Explosive eruptions of Klyuchevskoy produce significant amounts of pyroclastic material. Tephra layers deposited during winter seasons on the surface of the volcanic cone are commonly intercalated with layers of snow. Good temperature insulation provided by a blanket of vesicular tephra slows the melting process and the buried snow gradually transforms into ice that becomes a part of the geological structure of the volcano. It has been observed that at elevations of $4500-2700$ masl the uppermost $60 \mathrm{~m}$ of the volcanic cone is composed of volcanoclastic material containing $40-60 \%$ of ice (Vinogradov and Muravyev, 1985). This material creeps downslope at a speed of up to $10 \mathrm{~m} /$ year. At elevations of $4000-3000$ masl it forms eight glacier tongues covering a total area of $115 \mathrm{~km}^{2}$. There is a belt of "dead" (buried and not moving) ice around the volcanic cone at elevations of 2700-2200 masl, and permafrost approximately $100 \mathrm{~m}$ thick extends down to elevations of 700-800 masl.

On the upper slopes of the volcano there are three prominent ravines that descend radially toward SE, NW, and SW from the very edge of the summit crater, down to elevations of approximately $3000 \mathrm{~m}$. The ravines (up to several hundred meters across, up to three kilometers long, and several tens of meters deep) control the main paths of lava flows erupted from the summit crater. The ravines contain abundant accumulations of ice and snow (intercalated with frozen tephras and scoriacious autobreccias of lava flows). Most of the observed phreatomagmatic explosions occurred at lava flows moving downslope along the ravines.

\subsection{Secondary explosions during the 1994 eruption of Klyuchevskoy} volcano

\subsubsection{Observations}

The 1994 summit eruption was one of the strongest eruptions of Klyuchevskoy in the 20th century (Ozerov et al., 1997). The eruption 
started on 7 September after 11 months of dormancy. In the beginning it had a form of relatively weak Strombolian activity with ejection of glowing bombs from two vents to heights of up to $200 \mathrm{~m}$ and ash outbursts up to $500 \mathrm{~m}$ high (Fig. 1 of Supplementary material). The activity, although fluctuating, showed a gradual overall increase with time. By 12 September ash plumes reached $1-1.5 \mathrm{~km}$ and voluminous outpouring of lava from two vents located at the base of a growing intracrater scoria cone began. The lava flow quickly descended along the NW ravine down to an elevation of $2700 \mathrm{~m}$.

On 16, 17 and 30 September strong secondary phreatomagmatic explosions were observed along the lava flow at elevations of 27003500 masl. Each of these explosions lasted several minutes. Vertical ash-laden clouds from the explosions rose to heights up to $2-4 \mathrm{~km}$, while simultaneously from their sources ground-hugging clouds of pyroclastic flows (PFs) propagated downslope for 1-1.5 km (Fig. 1a). Formation of lahars up to $25 \mathrm{~km}$ long accompanied the secondary explosions.

During the evening of 30 September the activity of the volcano showed a conspicuous increase in intensity: the height of the bomb ejections reached $700 \mathrm{~m}$, and a new effusive vent with a high discharge rate was formed. From this vent another lava flow started to descend along the NW slope (parallel to the previous, still active lava flow). The total width of the lava field in the NW ravine reached $200 \mathrm{~m}$, with a length of approximately $5 \mathrm{~km}$.

At 05:00 h (local time) on 1 October, a climactic subplinian stage of the eruption started. It lasted approximately 10 hours during which continuous vigorous lava fountaining of up to $2.5 \mathrm{~km}$ high was accompanied by the uprise of a heavily tephra-laden eruptive column to $7-8 \mathrm{~km}$ above the summit crater (12-13 kmasl.). The eruptive plume drifted SE to a distance of more than $2000 \mathrm{~km}$ producing heavy ash falls.

Simultaneously with the intense explosive activity in the summit crater, large billowing dark gray ash clouds of violent secondary explosions up to $7 \mathrm{~km}$ high were observed on several occasions rising along the whole length of the lava flow field on the NW slope of the volcano at elevations of $3000-4800 \mathrm{~m}$ (Fig. $1 \mathrm{~b}$ and c). The explosions produced pyroclastic flows up to $2 \mathrm{~km}$ long that were observed from the ground from a distance of $30 \mathrm{~km}$ as well as at a much closer range from the helicopter (Fig. 1b and c). Voluminous lahars up to $30 \mathrm{~km}$ long were generated simultaneously with the formation of the PFs.

After the end of the climactic stage, the activity of the volcano quickly declined. On 2 October progressively weakening Strombolian explosions were observed; ash plumes rose less than $300 \mathrm{~m}$ high and the length of the active lava flow decreased to $1 \mathrm{~km}$. On 3 October the eruption ceased, although rare minor ash outbursts lasted for several more months.

\subsubsection{Pyroclastic flow deposits}

The pyroclastic flow (PF) deposits originated from middle-lower parts of the parental lava flow fields. No prominent explosion craters were found on the volcano slope in places where the secondary explosions occurred. When visited on the day following deposition, the freshly deposited PFs were hot to the touch, dry, gas-rich and very friable with signs of post-depositional degassing such as multiple small (several $\mathrm{cm}$ across) gas-escape vents surrounded by aprons of elutriated fines (Fig. 2b); no sublimates were found around the gasescape vents. The snow surface around the flows was covered by a thin (few $\mathrm{mm}$ ) layer of ash elutriated from the PFs. The PF deposits transformed downslope into lahar deposits composed of the same material mobilized by water.

The PF deposits formed during pre-climactic and climactic stages had similar characteristics and differed mostly in volume. Preclimactic PF deposits had a volume of $\sim 1-5 \times 10^{3} \mathrm{~m}^{3}$. They formed several individual lobes $0.5-1 \mathrm{~m}$ thick, $10-30 \mathrm{~m}$ wide that extended several hundred meters farther downslope than the parental lava flow (Fig. 2a). The individual PF lobes had steep frontal parts and small (tens of centimeters) well-defined lateral levees. The frontal parts of

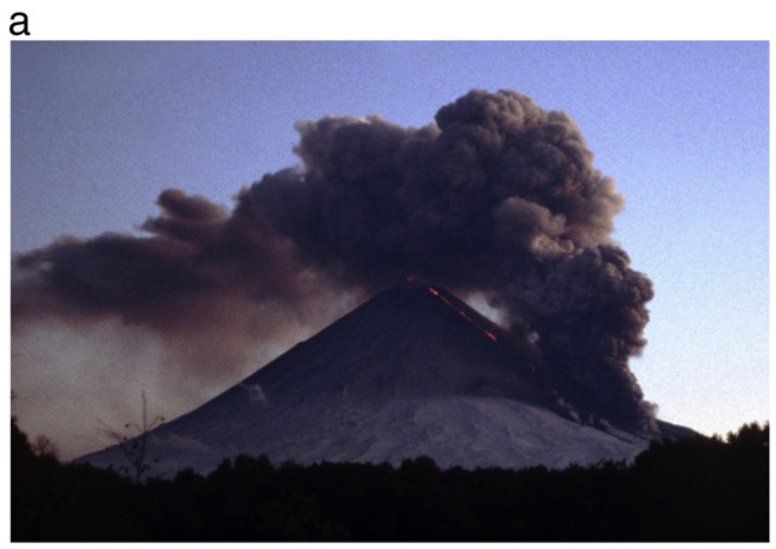

b

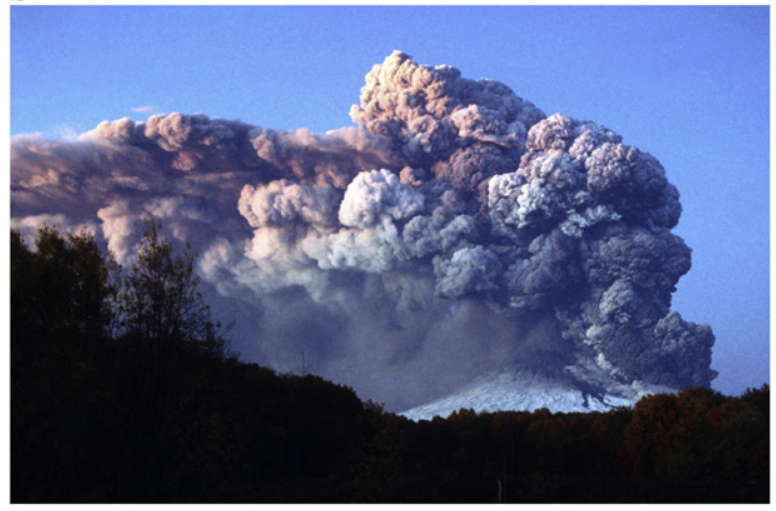

C

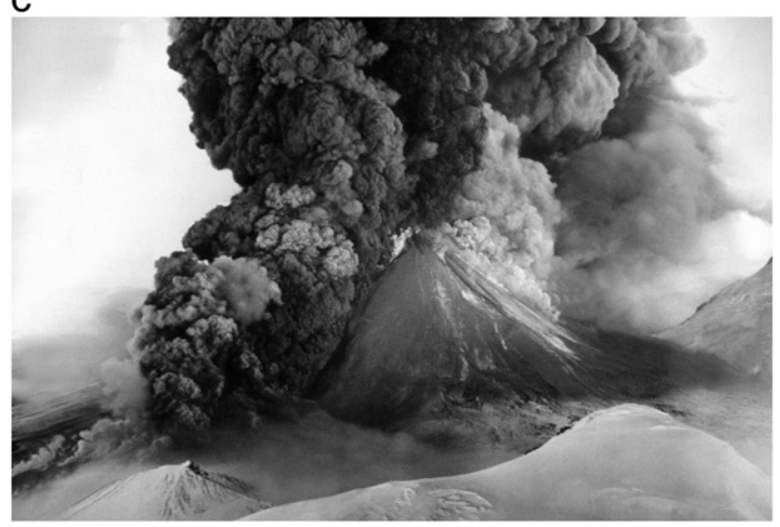

Fig. 1. Secondary rootless phreatomagmatic explosions with generation of pyroclastic flows during the 1994 eruption of Klyuchevskoy volcano. a - pre-climactic stage on September 30; cloud of the secondary explosion originates at front of the active lava flow at $3 \mathrm{kmasl}$ and rises up to $7 \mathrm{kmasl}$ (much higher than eruption cloud of the Strombolian eruption in the summit crater). b - climactic stage on October 1; clouds of secondary explosions rise up to $10 \mathrm{kmasl}$ ( $7 \mathrm{~km}$ above the explosion site) and partly obscure the subplinian column erupting from the summit crater and rising up to 12 kmasl. Black streams on slopes left by lahars. Both pictures by A. Belousov from Klyuchi town, $32 \mathrm{~km} \mathrm{~N}$ of the volcano. c - almost synchronous picture with b taken from helicopter by V. Podtabachny; pyroclastic flow on the NW (left) flank of the volcano (see also almost synchronous picture taken from the Endeavour space shuttle on Fig. 2a of supplementary material).

the lobes predominantly contained bombs-size clasts (Fig. 2b), while the internal parts of the flows were more matrix rich.

PF deposits formed during the climactic stage of 1 October had a volume of $1-5 \times 10^{6} \mathrm{~m}^{3}$. They traveled to a distance of more than $2 \mathrm{~km}$ from the fronts of the parental lava flows. Multiple intercalated flow lobes (similar to those described above) formed three extensive fanshaped compound fields (a few hundred meters across) at elevations 2500-2700 m (Figs. 2c and 3). The thickness of the largest field exceeded $10 \mathrm{~m}$. 
a

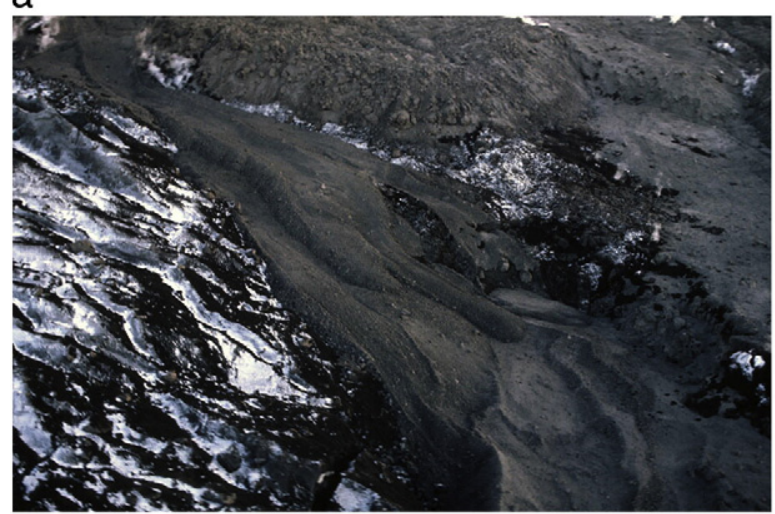

C

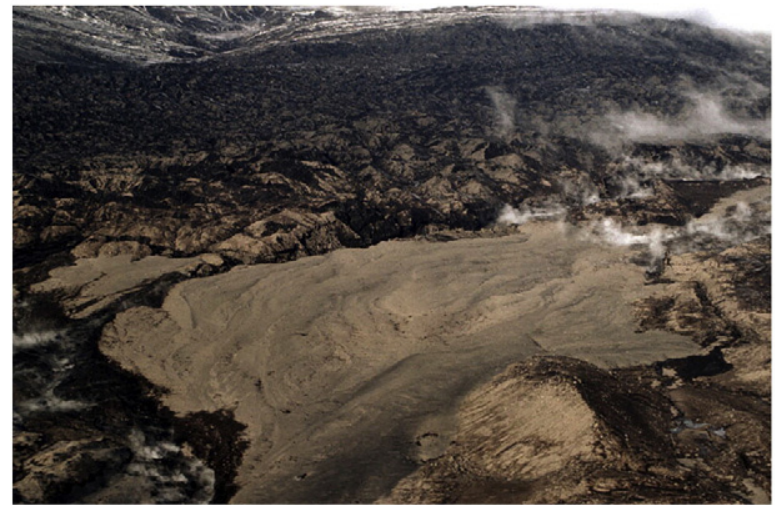

b

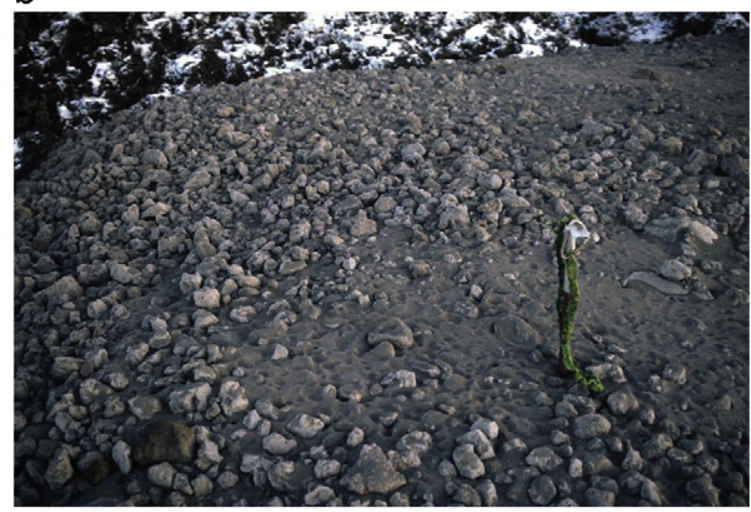

d

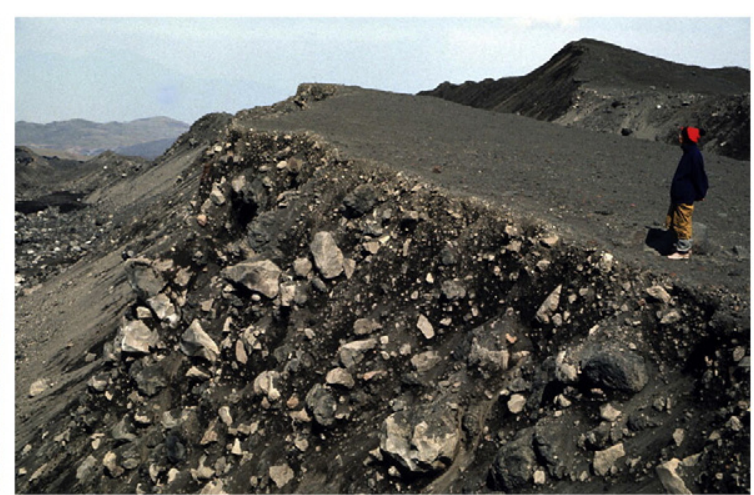

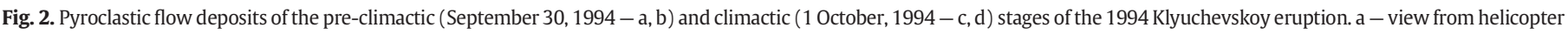

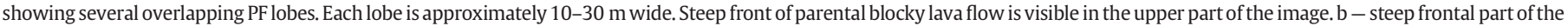

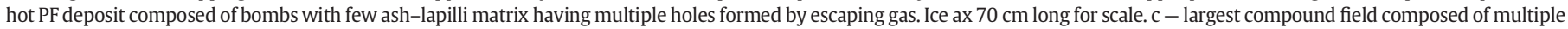

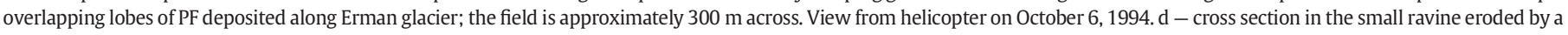
temporary stream. By the time the picture was taken (August 1998) the deposit was tilted due to motion of the underlying glacier. Photos by A. Belousov.

Cross section of the largest PF field was studied in 1998, when it had been partially exposed by water erosion. The deposit was matrixsupported with no apparent stratification; bomb-size clasts were almost uniformly distributed through the cross section (Fig. 2d), with a poorly developed concentration of largest clasts in the middle-lower part of the outcrop. The deposits were composed of sub-angular to sub-rounded rock fragments up to 5-40 cm across (in climactic PFs up to $2 \mathrm{~m}$ ) set in a fine-grained matrix (Fig. $2 \mathrm{~b}$ and $\mathrm{d}$ ). The bomb-size clasts were represented mostly by rather uniform dark gray, dense to poorly vesiculated basaltic andesite typical for lavas of summit eruptions of Klyuchevskoy. Small percentage of the clasts was represented by reddish oxidized variety.

The $10-20 \%$ of the bomb-size clasts in the PF deposits has a peculiar surface morphology: the uppermost several centimeters of their outer surface is quenched and ruptured by a dense network of thin, crisscrossing cracks. The cracks have different orientations in plane view, but their planes in many cases are normal to the surface of the bombs (Fig. 3a of Supplementary material). In some cases, the outer part of the bombs is so strongly fractured that resembles partly welded breccia. The internal parts of the bombs are not fractured. Some bombs in the deposits have cauliflower surface morphology (Fig. 3b of Supplementary material).

Ash-size particles of the PF matrix show an irregular, blocky shape (Fig. 4a-d). The particles are either dense or contain rare 50-200 $\mu \mathrm{m}$ oval smooth-surfaced gas bubbles separated by thick walls. Particles are bounded by irregular planes having multiple chip-off marks. Adhering dust (1-10 $\mu \mathrm{m}$-size angular clasts) is common at the surfaces of the particles.

Matrix of PF deposits is composed by lapilli and coarse ash (Fig. 5a). Histograms of the grain-size distribution of the PF material are bimodal with -4 to -6 phi and 1 to 2 phi modes subdivided by -1 to -2 phi minimum. Samples from the frontal parts of the PF deposits show a larger coarse-grained mode (Fig. 4 of Supplementary material). The deposits are poorly sorted and in the Md/sorting plot fall into the area common for PFs (Fig. 5b). Grain size characteristics of the PFs are very similar to grain size characteristics of the simultaneously deposited lahars (Figs. 5a and 4 of Supplementary material). Density distributions of the PF material have one well-defined mode $2.2-2.6 \mathrm{~g} / \mathrm{cm}^{3}$ corresponding to vesicularity 8-22\% (Fig. 5c).

\subsection{Secondary explosions during other eruptions of Klyuchevskoy volcano}

\subsubsection{Summit eruptions}

The most powerful secondary explosions at Klyuchevskoy occurred at lava flows emitted from the summit crater (e.g. Vinogradov et al., 1987; Belousov, 1990). Such explosions have been observed (although their phreatomagmatic character was not always recognized) at almost all lava flows erupted from the summit since 1935 when detailed monitoring of the Klyuchevskoy began. Obviously such explosions occurred before that time also, but only few of them (in 1829 and 1909) were mentioned in brief and incomplete accounts of the past (Piip, 1956).

The strong 1944-1945 eruption of Klyuchevskoy was in many aspects similar to the 1994 event (Piip, 1956; Ozerov et al., 1997). During the climactic subplinian stage on 1 January 1945 the vertical eruption column rose $10 \mathrm{~km}$ above the summit crater. Simultaneously with the vertical eruption column, multiple PFs (Fig. 6a) descending the NW slope of the volcano were observed (called "hot avalanches" by Piip, 1956). Along the path of these PFs a deep new ravine was formed on the NW slope of the volcano. Deposition of the PFs was 


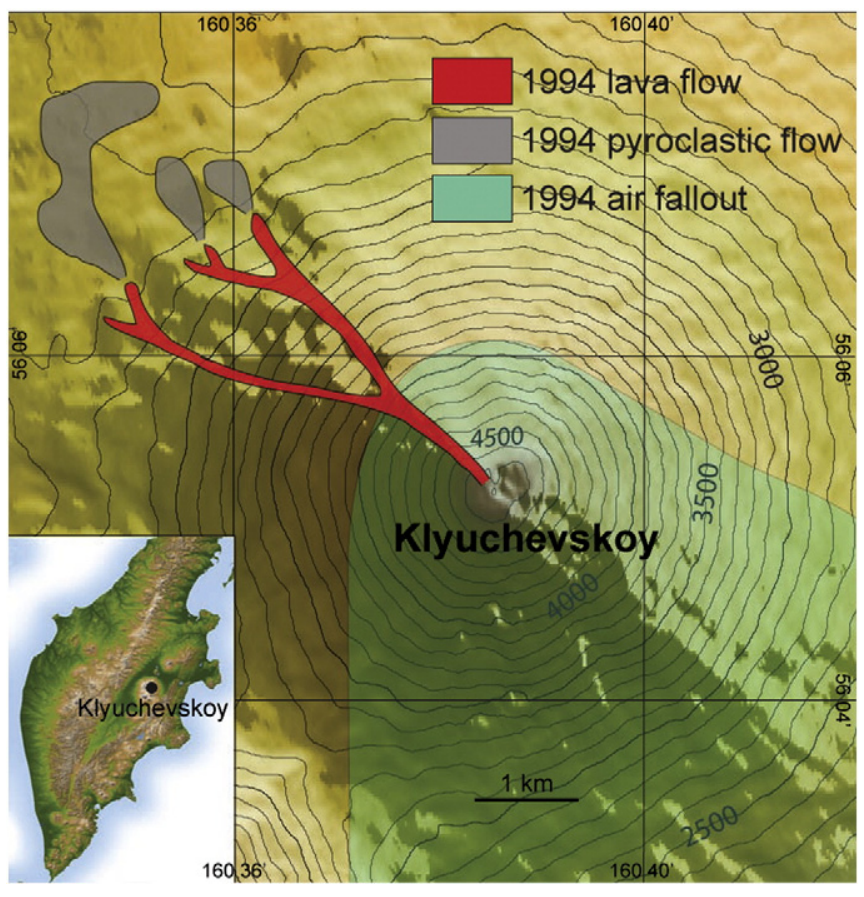

Fig. 3. Sketch map of the deposits produced by the climactic stage of Klyuchevskoy eruption on October 1, 1994 with inset showing location of Klyuchevskoy volcano in Kamchatka Peninsula.

accompanied by the formation of voluminous lahars that reached the Kamchatka River (35 km from the volcano).

Deposit of the PFs extended from 2700 to 2000 masl, covering an area $7 \mathrm{~km}^{2}$ with a maximum thickness of $60 \mathrm{~m}$ and an average thickness of approximately $20 \mathrm{~m}$ (Piip, 1956). Volume of the deposit comprised $0.14 \mathrm{~km}^{3}$, of which $35 \%\left(0.05 \mathrm{~km}^{3}\right)$ was represented by non-juvenile materials (lavas and pyroclasts of previous eruptions). Juvenile bombsize clasts were up to $2 \mathrm{~m}$ in diameter and had quenched and fractured surface resembling "broken ice". The PF deposit was hot and gas-rich; plumes of fumaroles up to $600 \mathrm{~m}$ high were seen until 2.5 months after the eruption. The origin of the PFs was attributed by Piip to massive pyroclastic fallout from the summit eruption onto the slope of the volcano - a process that is known now as partial eruption column collapse. The description of Piip (1956) is the first detailed reliable account of formation of pyroclastic flows at Klyuchevskoy volcano (a "flow of friable material" was mentioned also in descriptions of the 1925 summit eruption, but the character of that deposit is unclear).

One notable difference between the courses of the 1994 and 1945 eruptions is that outpouring of lava flow prior and during the climactic stage in the 1945 eruption was not observed. Lava was noticed for the first time in the newly formed NW ravine immediately after the 1 January 1945 paroxysm, and lava effusion continued for 20 days afterwards. Our observations of the 1994 eruption have shown that the discharge rate of lava strongly increased during the onset of the climactic stage. Thus, we argue that on 1 January 1945 intensive outpouring of lava from the summit crater on the NW slope actually started at the onset of the climactic stage, but was obscured by the falling ash. Similar characteristics of the PF deposits of the 1945 and 1994 eruptions indicate that in both cases the PFs originated from secondary phreatomagmatic explosions at active lava flows.

A series of powerful explosions was observed on 2 December 1985 in the NW ravine at elevations $3600-4300 \mathrm{~m}$ (Belousov, 1990; Zharinov et al., 1990). The explosions occurred along active lava flow (Fig. 6b) and followed one another in rapid succession, while the sources of individual explosions gradually moved upslope. The resulting ash-laden cloud rose up to $9.6 \mathrm{kmasl}$. From the base of the eruption column a ground-hugging cloud resembling a PF was seen descending downslope. Lahars up to $30 \mathrm{~km}$ long accompanied the explosions. The 1985 PF deposits were not investigated. Ash fall deposit that resulted from the secondary explosions was unusually fine-grained, fraction $<0.063 \mathrm{~mm}$ composed of $59-72 \%$ by weight (Fig. 4 of Supplementary material). The ash contained significant proportion of non-juvenile particles (Belousov, 1990).

Similar but smaller scale secondary explosions accompanied by ground-hugging clouds descending downslope were observed at lava flows of the 1987, 1993, 2005, 2007 and 2008 summit eruptions (Figs. 6c and $2 \mathrm{~b}$ of Supplementary material). Eruptive plumes of these explosions containing moderate amounts of ash reached $2-4 \mathrm{~km}$ above the sources. The March 9, 2005 pyroclastic flow was photographed by a tourist from a close distance. The moving flow had broad cuspate billowing frontal part similar to frontal parts of pyroclastic flows observed elsewhere. The deposit of the flow was not studied.

\subsubsection{Flank eruptions}

Secondary phreatomagmatic explosions were also common at lava flows of flank eruptions of Klyuchevskoy occurring at the gently sloping foot of the volcano (Vinogradov and Muravyev, 1985). In contrast to secondary explosions on lava flows from summit eruptions, these were weak, even in cases when eruptions occurred directly through glaciers, and lava had direct contact with ice and frozen volcanoclastic rocks over broad areas (flank eruptions in 1937, 1966, 1974, and 1988). Eruptive clouds of these secondary explosions rose only up to a few hundred meters above the sources and contained little ash; no PFs were formed.

\subsection{Discussion: mechanism of the explosions and PF formation at Klyuchevskoy}

Three principally different mechanisms were suggested to explain the origin of the PFs at Klyuchevskoy: (1) partial collapse of the eruption column rising from the summit crater (Piip, 1956); (2) secondary phreatomagmatic explosion at a lava flow (Belousov, 1996); (3) gravitational collapse of active lava flow (Dvigalo and Melekestsev, 2000). Visual observations alone did not provide clear clues about the mechanism, especially for PFs formed during the climactic subplinian stages when heavy ash falls from summit eruption clouds partially obscured the view. Thus all the available data are considered below to elaborate on the mechanism of the PF formation.

Juvenile particles in the described PFs of Kliuchevskoy are represented almost exclusively by dense, non-vesicular to poorly vesicular material, whereas juvenile particles erupted from the summit crater (air fallout deposits of Strombolian and subplinian eruptive columns) are represented by low density, highly vesicular scoria (Figs. 4 and $5 \mathrm{c}$ ). The drastic difference in density/vesicularity shows that the PFs were not formed as a result of partial or total collapse of the eruptive columns of central crater. As was frequently observed, formation of the PFs occurred due to some unknown explosive process on active lava flows descending along the steep volcano slopes (Figs. 1 and 6).

Formation of the studied PFs may be caused either by gravitational collapse of lava having high autoexplosivity as is typical for silica-rich lava flows e.g. at Merapi volcano (Fisher and Schmincke, 1984) or/and by secondary explosion. The slopes of Klyuchevskoy are very steep and thus gravitational collapses of active lava flows outpouring from its summit crater are common. Such collapses generate avalanches of large bouncing glowing blocks containing little fine-grained material (unpublished observations of $\mathrm{AB}$ ); they are not accompanied by significant ash clouds and look rather different from the described PFs. Lava flows of Klyuchevskoy, being of mafic composition $\left(\mathrm{SiO}_{2}=51-54 \%\right)$, are less viscous and more degassed (i.e. they have much lower autoexplosivity) than their silica-rich counterparts and thus in the process of collapse do not produce significant volumes of fine-grained material. Thus purely 


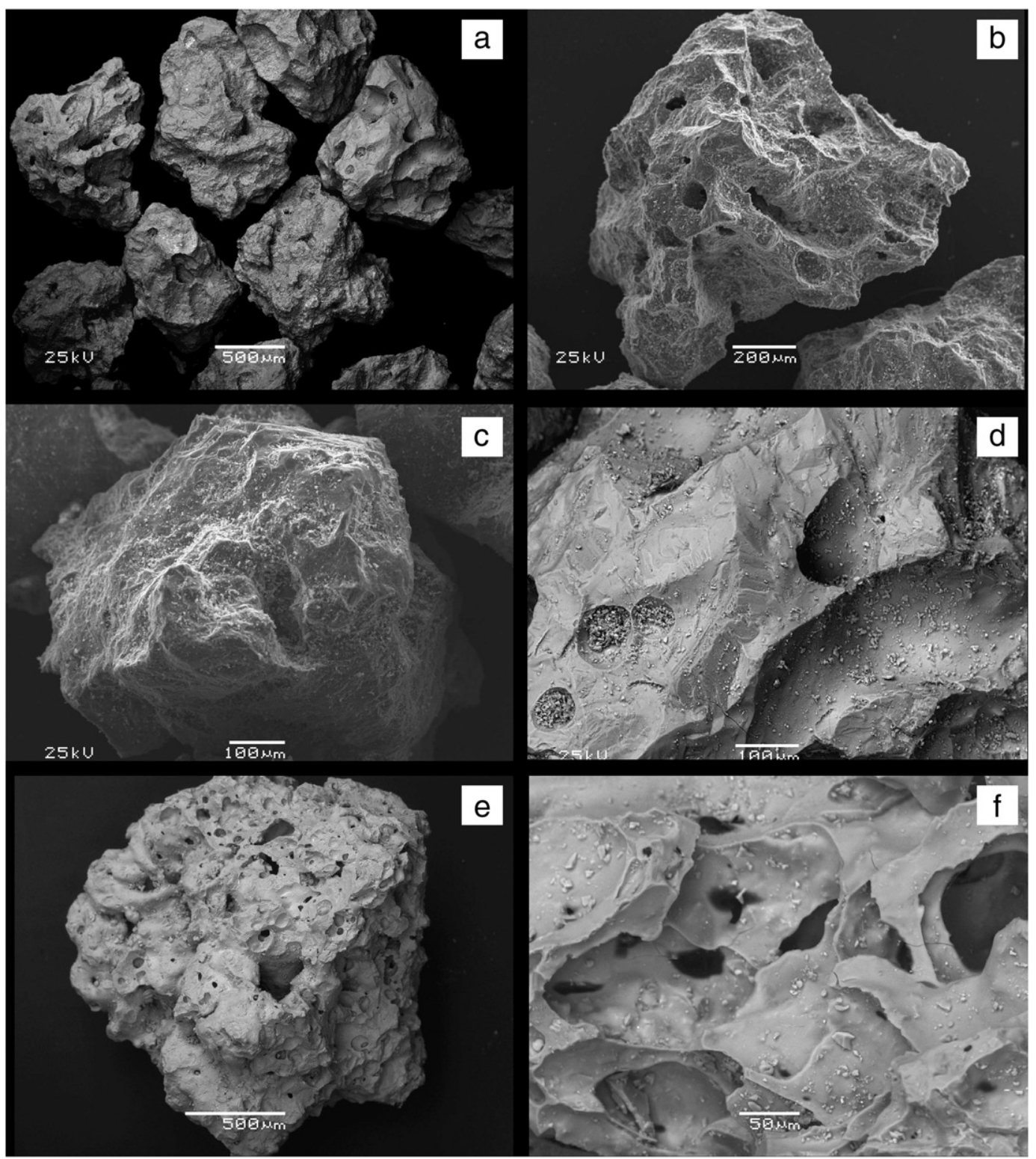

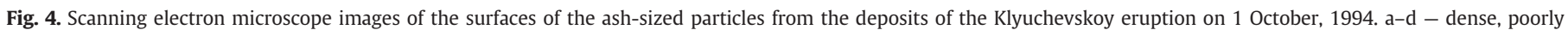
vesicular blocky particles from pyroclastic flows formed by secondary explosions. e-f - vesicular scoria of ash fallout from subplinian eruption in the summit crater.

gravitational collapse of lava flows cannot explain the origin of the PFs at Klyuchevskoy.

Abundance of fine particles in the PF deposits as well as surface morphologies of the juvenile clasts (bomb-size clasts have quenched strongly fractured or cauliflower surfaces; ash-size particles are blocky with chip-off marks) indicate highly energetic fragmentation of lava as a result of contact with external water - MFCI (e.g. Wohletz, 1983; Heiken and Wohletz, 1985; Büttner et al., 1999; Morrissey et al., 2000; White and Houghton, 2000; Belousov and Belousova, 2001; Büttner et al., 2002). Voluminous lahars, simultaneously outpoured from the locations of explosions, indicate that water was available in large amount in the moment of the PF generation. Thus explosive interaction of lava and water should be considered as the main mechanism of fragmentation providing large quantity of fine-grained material necessary for the formation of the PFs.

The only source of water on the steep volcano slope can be water resulting from melting of ice in ice-saturated rocks and lenses of snow and ice buried by volcanoclastic material. We suggest that the melting occurred gradually under the advancing lava flows, and the melt water was accumulated in the form of lenses of water-volcanoclastic slurry in the base of the lava flows. Explosive interaction of lava with water-volcanoclastic slurry formed due to thawing of substrate of lava flows explains the high proportion of old material in the products of the secondary explosions (both in the fallout and the PF deposits).

It is well known that MFCI between subaerial lava flows and external water is limited and in many cases lava advances across wet/frozen terrain or enter surface water bodies without significant explosive activity. This occurs because very different properties of the two liquids (lava and water) prevent hydrodynamic intermixing processes in an unconfined environment (Zimanowski and Wohletz, 2000). What has helped to intermix very viscous, partly solidified lava with the water-volcanoclastic slurry to make their interaction very energetic? The clue can be inferred from the fact that violent secondary explosions with formation of PFs occurred only at lava flows descending from the summit crater over steep slopes $\left(>15^{\circ}\right)$. Secondary explosions at lava flows from flank eruptions of Klyuchevskoy (even those erupted through glaciers) that occurred at gentle slopes $\left(<15^{\circ}\right)$, were less vigorous and never produced PFs. Occurrence only on steep slopes, strongly elongated "sources" of the explosions, and absence of resulting explosion craters allow to suggest that the key process leading to intensive intermixing of lava and 


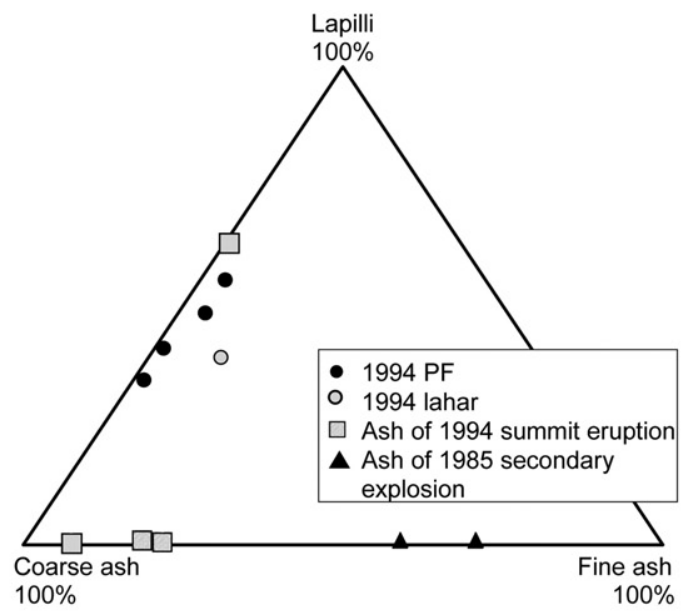

b

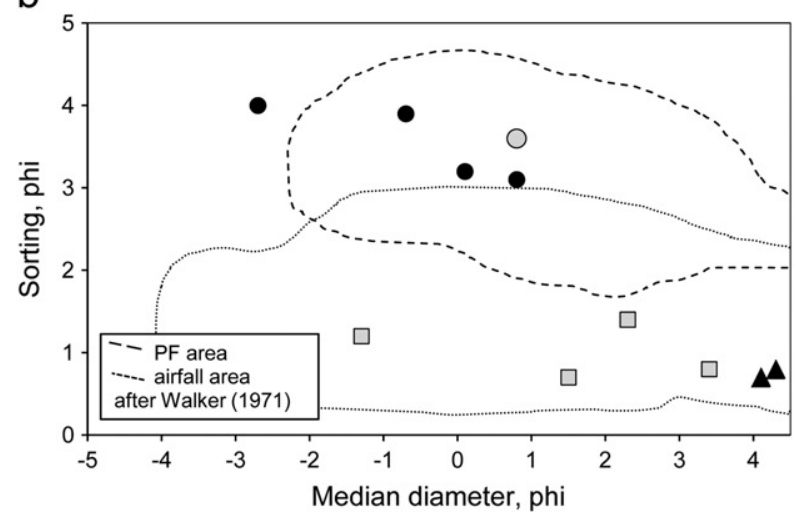

C
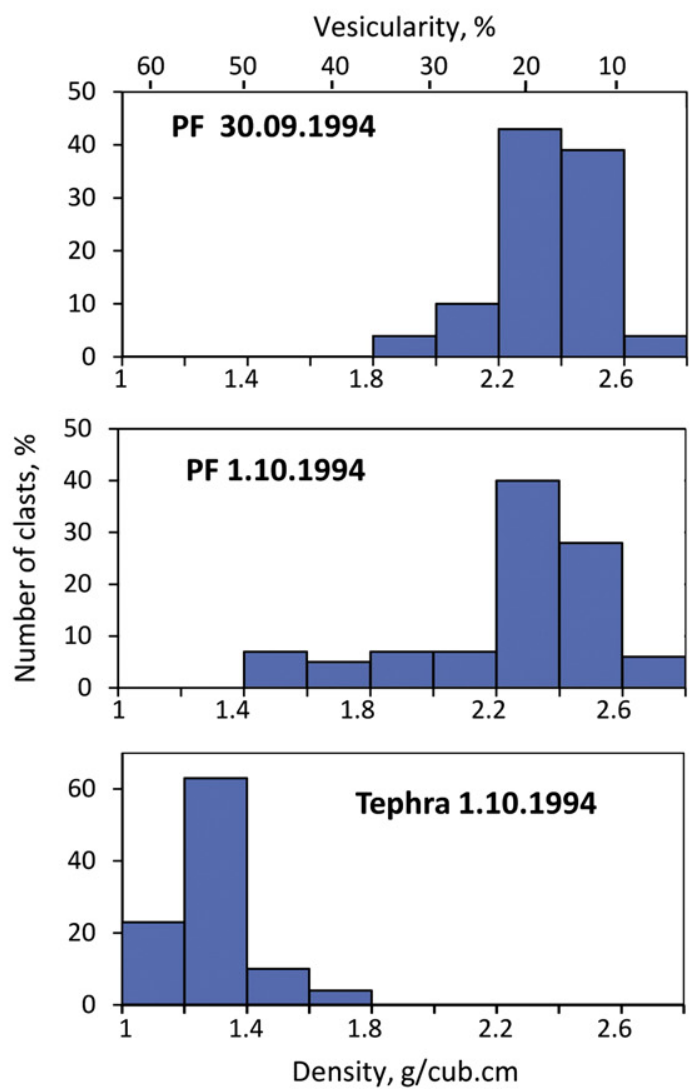

volcanoclastic slurry was gravitational sliding of lava flow involving also some volume of water-saturated substrate. Removal of up to $37 \mathrm{~m}$ of thickness of the lava flow field was detected by fotogrammetric method after the 1985 secondary explosions (Dvigalo and Melekestsev, 2000). Probably the main reasons leading to the collapse were: (1) growth of the lava field (increase of gravitational loading); (2) melting of snow and ice contained in the substrate (weakening of mechanical properties of the slope); and (3) heating and boiling of the melt water in the substrate (growth of pore pressure). An additional reason could be gradual growth of hydrostatic pressure in the lower, downslope part of the lens of watersaturated rocks sealed between the impermeable frozen slope and the overlying lava flow (while the along-the-slope length of the lens increased, following the increase of the length of the lava flow).

Summarizing the above, we suggest the following mechanism of secondary explosions and PF generation at Klyuchevskoy (Fig. 7). Lava flow advances on a steep slope composed of various volcanoclasts containing up to $60 \%$ of ice. Gradual heating and thawing of the frozen substrate form a lens of water-volcanoclastic slurry in the base of the lava flow. Water can be overheated and boil along the contact with the lava flow. Such as the lens of slurry is mechanically weaker than the initially frozen substrate, at some moment gravitational instability appears that can be additionally increased by growth of pore pressure in the lens due to heating and boiling of water. Increase of the length of the water-volcanoclastic slurry lens underlying the lava flow may also play a role in the growth of the pore pressure. These processes eventually lead to sliding of a part of the lava flow and the thawed substrate. Possibly the failure-induced unloading of the lithostatic pressure from overheated steam/water-saturated substrate causes powerful outbursts of steam in the initial moment of sliding ("pressurized bowl" type of explosion). The collapsing lava partially disintegrates and intermixes with the slurry, triggering highly explosive "fuel-coolant" type interaction similar to that proposed by Kokelaar (1983) for shallow submarine eruptions. The lava/slurry interaction causes additional pervasive fragmentation of the lava providing plenty of fine-grained hot pyroclastic (hydroclastic) material. The produced gas/pyroclast mixture is much heavier than air (relatively low temperature, mostly water vapor as a gas phase, high concentration of fine-grained and dense clastic material). Thus only a small volume of the gas/pyroclast mixture forms a vertical eruption cloud, while most of it is not buoyant and thus continues to descend downslope in the form of a pyroclastic flow. In the case when there is excess of water released by the sliding (which is not completely interacted with the molten lava), it forms a lahar.

\section{Etna volcano}

Here we consider three cases during the 2006-2007 eruptions of Etna, when secondary explosions and PFs similar to those described on Klyuchevskoy were observed.

\subsection{Background}

Mount Etna (summit elevation 3329 masl of mid-2007) lies in eastern Sicily, Italy. Like Klyuchevskoy it is among the most frequently active and productive volcanoes on the Earth. During the past millennia, Etna has erupted alkalic basalts (hawaiites or trachybasalts; Tanguy et al., 1997) in mostly effusive eruptions from its summit craters and numerous vents on its flanks. However, moderately explosive (VEI 2-3) Strombolian activity is frequent especially during summit eruptions, and subplinian to Plinian summit eruptions have occurred repeatedly during the late Holocene

Fig. 5. Characteristics of pyroclastic material of Klyuchevskoy volcano. a - ternary diagram of grain size composition (lapilli $<-1$ phi, coarse ash from -1 to 4 phi, fine ash $>4$ phi). b - sorting vs median diameter for the same deposits; Inman coefficients. c - density/ vesicularity histograms for the 1994 PFs and subplinian tephra; determined by method of Houghton and Wilson (1989) for fractions 1-4 cm; vesicularity values calculated using dense rock equivalent of $2.8 \mathrm{~g} / \mathrm{cm}^{3}$. 
a

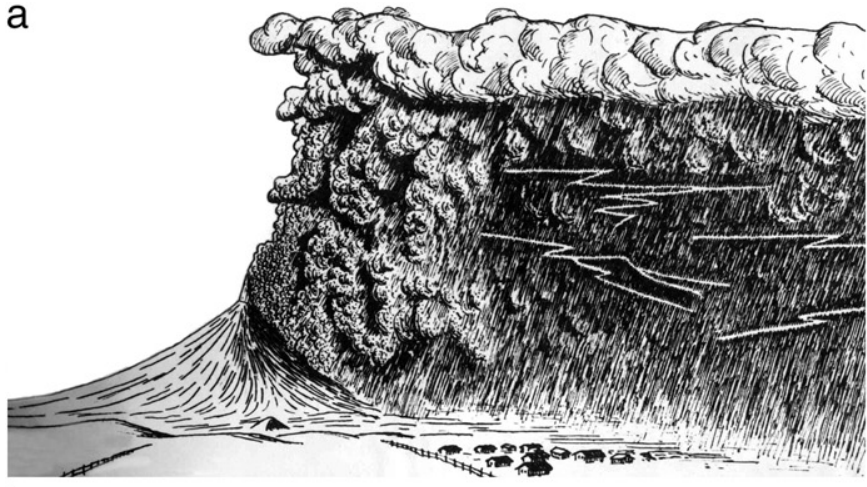

b

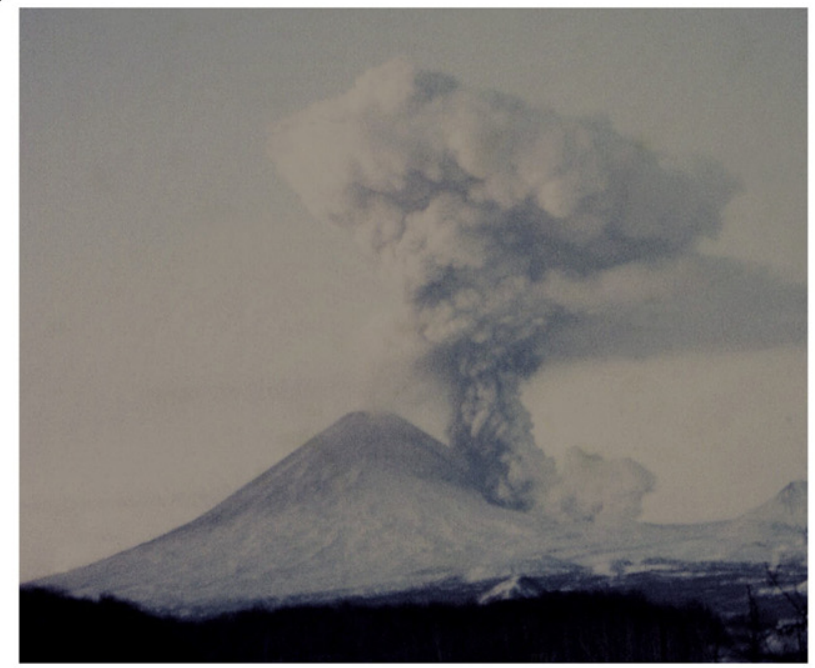

C

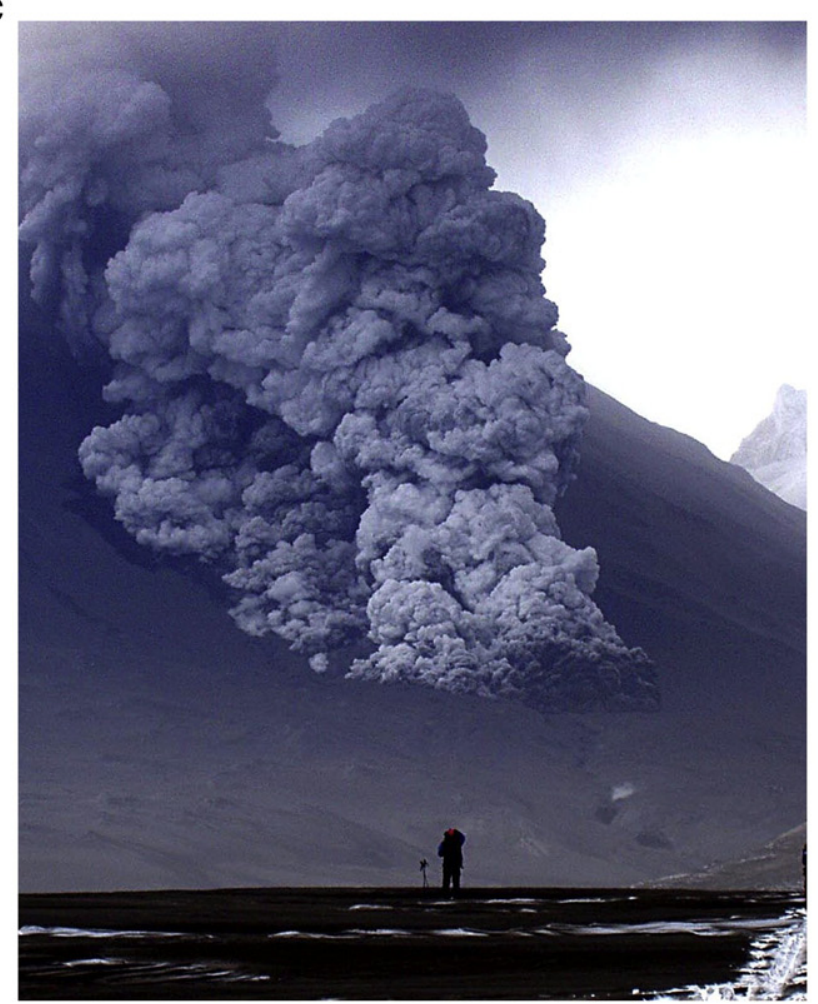

Fig. 6. Secondary rootless phreatomagmatic explosions at lava flows with generation of pyroclastic flows during summit eruptions of Klyuchevskoy. a - climactic stage on January 1, 1945; drawing by Piip (1956). b - December 2, 1985; photo by A. Belousov. Heights of the eruptive clouds are accordingly 14 and 10 kmasl; view from Klyuchi town, $32 \mathrm{~km} \mathrm{~N}$ of the volcano. c - pyroclastic flow on NW slope; March 9, 2005; photo by A. Lobashevsky. including a number of short-lived subplinian paroxysms in recent decades. Although there is some reference to phreatomagmatic volcanism at Etna (e.g. Chester et al., 1985), this kind of activity has received little appreciation as a potential hazard.

PFs have been considered a rather exotic phenomenon during modern eruptions of Etna. The recognition that small PFs are a rather frequent product of Etna's summit eruptions follows eight events documented for the past 20 years (Behncke et al., 2008; Behncke, 2009).

\subsection{Conditions on the slopes of Mount Etna}

The upper slopes of Etna vary strongly in their inclination, from the nearly flat areas surrounding the summit cones especially to the S, SW and $\mathrm{N}$, to the steep slopes of the summit cones themselves. Rapid accumulation of eruptive products on these cones, often leading to vigorous cone growth, has repeatedly led to gravitational failure of limited portions of these edifices, as observed in 1964 and 1999 (Calvari and Pinkerton, 2002). A further factor potentially facilitating structural instability at Etna's summit is the pervasive hydrothermal alteration affecting various zones of the summit cones, which is most pronounced at the Southeast Crater, the youngest and steepest of these features. The unstable and fluid-saturated fumarolized areas are frequently subject to burial by lava flows and other eruptive products, as well as to the opening of eruptive fissures, crater rim breaching, or wholesale removal of larger portions of the summit edifices (Behncke et al., 2006).

Mount Etna is covered with snow during winter, with near-continuous snow cover on at least the uppermost few hundred meters of the edifice from December to March; large areas of snow often survive until late May (personal observations of BB). Snow accumulations are most pronounced in the relatively flat areas surrounding the base of the summit crater complex, but can be significant also on the steep upper W slope of the Valle del Bove depression on the E side of the volcano. Snow thicknesses can exceed $10 \mathrm{~m}$ in sheltered areas especially after periods of persistent precipitations. As at Klyuchevskoy, tephra layers (including wind-blown ash) frequently cover and protect snow layers that can remain conserved within the substrate for many years to a depth of possibly several tens of meters below the surface, and at altitudes down to 2000 masl.

3.3. Secondary explosions with formation of PFs during the 2006-2008 eruptions

\subsubsection{Observations}

The explosions occurred during a period of intermittent eruptive activity from July 2006 until May 2008. This activity was associated with the Southeast Crater (SEC) and varied from quiet lava effusion over semipersistent Strombolian activity to episodes of powerful lava fountaining accompanied by high-rate lava outflow and the uprise of dense tephra columns. A particular feature of this eruptive period was frequent shifting of eruptive vents at the SEC itself, and the opening of multiple, mostly effusive lateral vents at distances of up to $1 \mathrm{~km}$ from the SEC.

Three paroxysmal eruptive episodes during this eruptive period, on 16 and 24 November 2006, and 29 March 2007, were accompanied by vigorous secondary phreatomagmatic explosions that generated PFs (Behncke et al., 2008; Norini et al., 2009).

\subsubsection{6 and 24 November 2006}

Volcanoclastic flows of various scales and origins were observed during both paroxysmal eruptive episodes on 16 and 24 November 2006 (Behncke et al., 2008; Behncke, 2009; Norini et al., 2009). We will focus here on the formation of the two largest PFs that were formed as a result of secondary explosions on lava flows. These secondary explosions were somewhat different from the others described in this paper, because they occurred on slopes that were free of snow or frozen rocks. In contrast, in these cases lava flows interacted with substrate saturated with hydrothermal fluids (Behncke et al., 2008; Behncke, 2009). 
1. Advancing lava flow, gradual thawing of ice in the substrate Immediately below the lava flow a lense of pressurized overheated steam is forming.

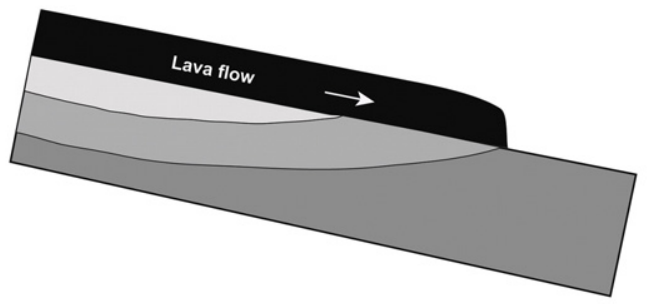

3. Disintegration of sliding lava and its intermixing with water-saturated substrate. Explosion due to lava/volcanoclastic slurry interaction (MFCl)

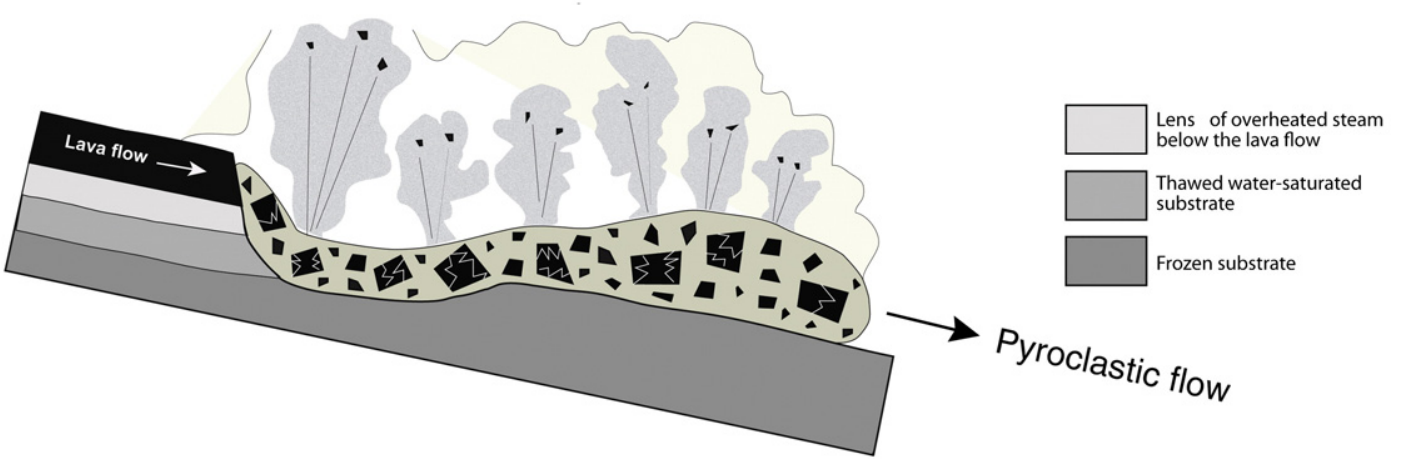

2. Gravitational failure of lava flow and thawed substrate. Initial "pressurized bowl" type explosion(s).

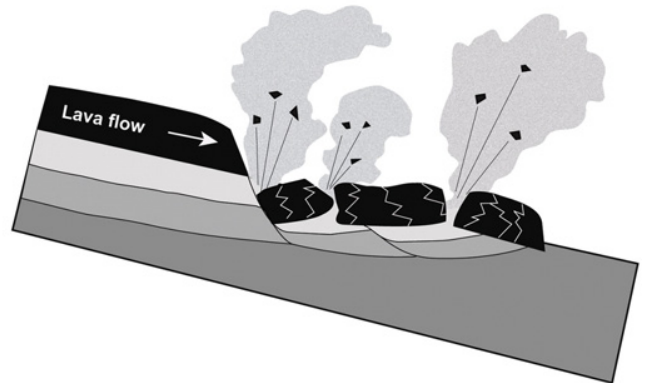
any part of active lava flow (not only at the front)

Both, the 16 and 24 November eruptive paroxysms in the primary volcanic vents lasted approximately 10-12 hours each. The largest pyroclastic flows were formed during the waning phases of the paroxysms and originated from locations away from the primary vents. Thus, the processes that generated these flows were not directly related to the eruption intensity.

On 16 November all eruptive activity at the SEC was confined to a cluster of vents at its summit. The summit vents displayed vigorous Strombolian activity and emitted lava flow that descended along the ESE flank of the cone, but also found its way into the SE flank. Dynamic action (intrusion and erosion) of the lava on the SE flank caused slow slumping (accompanied by multiple small rock avalanches) of a sector of the SEC slope. The slumping block was consisted mostly of old scoria and spatter saturated with hot hydrothermal fluids. Much of the slumping occurred simultaneously with emplacement of active lava flow in the same area; lava intermittently interacted with the slumping wet material, as testified by frequent small secondary explosions that ejected white steam, brown to black ash clouds and non-incandescent ballistic blocks.

Detailed analysis of the available photographic and video records of the 16 November events has shown that by 14:00 GMT, the slumping had formed a large scar in the slope of the SEC (see detailed description and photos in Behncke et al., 2008). Just below the scar, at the lower slope of SEC, the slumping block gradually disintegrated and flattened; it emitted steam and small sprays of ash, steam, and non-incandescent blocks from shifting locations. At 14:25 GMT a series of noiseless explosions producing vigorous vertical tephra and steam jets started to burst from the central portion of the slowly slumping block and then extended both up- and downslope, culminating in the generation of a major PF (Fig. 8a). The flow consisted of a slower, more extensive white cloud containing abundant steam and few pyroclasts, and a more rapid, denser, dark grayish-brown topography-controlled undercurrent. The flow reached a distance of $\sim 1.2 \mathrm{~km}$ from its source, traveling at a speed of $70-100 \mathrm{~km} / \mathrm{h}$.

The PF on 24 November at 08:17 GMT originated from the same general area as the PF on 16 November 2006. It was recorded on video footage of the Schiena dell'Asino INGV-CT monitoring camera (approximately $5 \mathrm{~km}$ from the crater) and by a tourist. The initiation of this flow was also clearly explosive. The video footage (Fig. 5 of Supplementary material) shows the appearance of profuse steam (and possibly minor ash) emission from a spot at the base of the SEC cone as early as 08:13 GMT. This steaming spot abruptly started to move downslope at 08:17-08:26, and was followed by a voluminous cloud of white steam and dark gray ash. The speed of the PF, determined from the footage, was $120 \mathrm{~km} / \mathrm{h}$. Secondary explosions continued to occur for several hours from different locations on the PF deposit, producing steam and ash clouds that rose several hundred meters high.

\subsubsection{March 2007}

During 2007 and early 2008, sporadic eruptive activity occurred at the SEC, punctuated by 7 paroxysmal eruptive episodes. The eruptive episode on 29 March 2007 was characterized by violent explosive interaction between flowing lava and snow/wet or frozen substrate that led to the formation of relatively small PFs (Behncke, 2009).

The 29 March paroxysm was a short-lived ( $<1 \mathrm{~h}$ ) and quite violently explosive event (see detailed description and photos in Behncke et al., 2008). Three lava flows were erupted, two from the vents lying to the WSW of the SEC, and a third, much more voluminous one descended from the summit vent of the SEC toward the Valle del Bove. This latter flow traveled across terrain buried under up to $10 \mathrm{~m}$ of freshly fallen snow. Interaction of lava and snow and wet or frozen substrate led to continuous explosions within an elongated zone on the steep W slope of the Valle del Bove, ejecting material to a distance of tens of meters. Tephra-charged clouds of steam were observed to spill downslope from the explosion area, forming small PFs that reached the base of the steep slope. Formation of small lahars accompanied formation of the PFs.

\subsubsection{Deposits}

Only the PF deposit formed on 16 November 2006 was studied (Behncke et al., 2008; Norini et al., 2009); the published data are summarized below. The deposit is represented by two different facies: a valley-filling, thick, coarse-grained facies and a more extensive, thin, fine- 
a

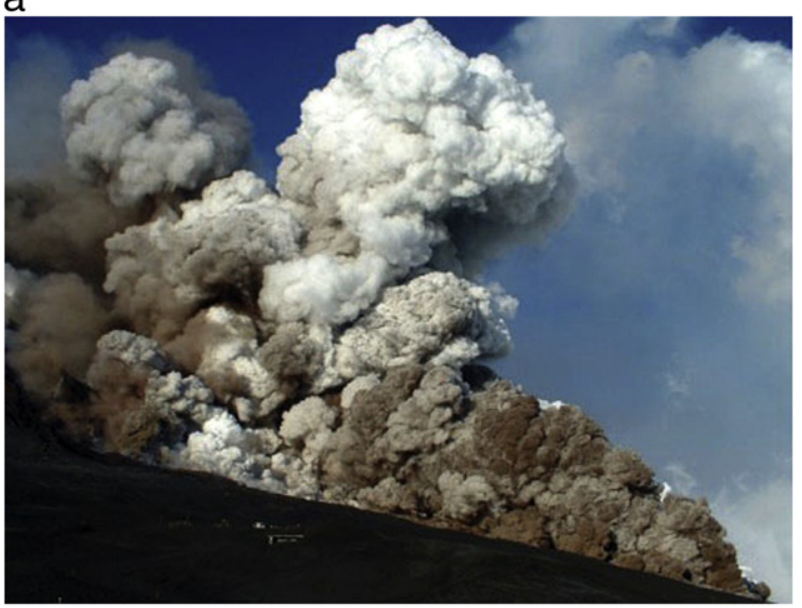

b

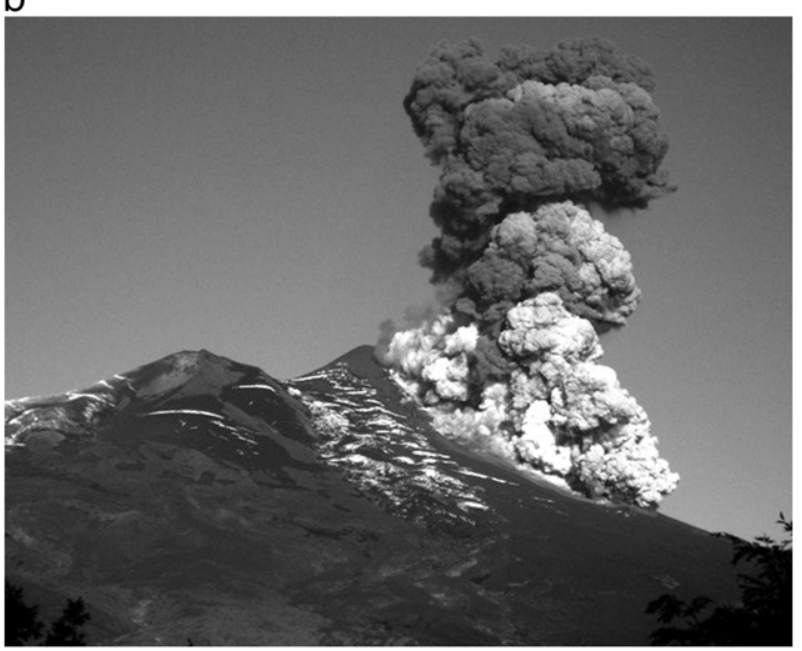

C

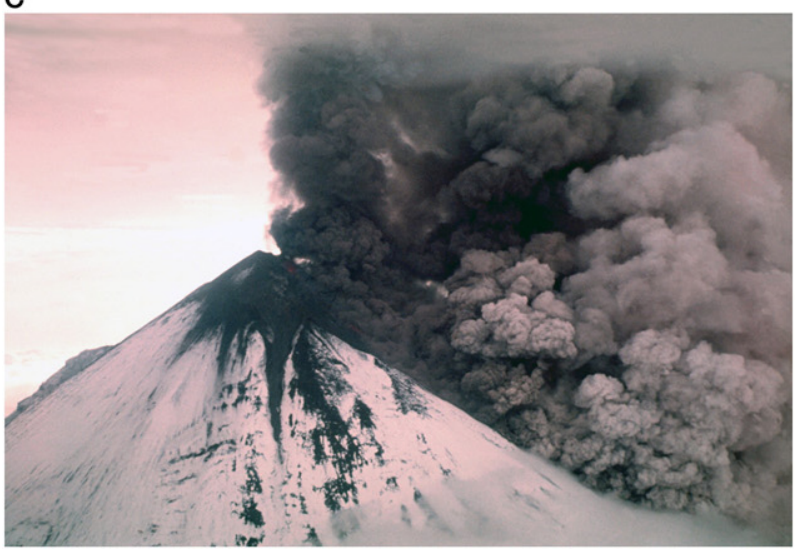

Fig. 8. Secondary rootless phreatomagmatic explosions at lava flows with generation of pyroclastic flows. a - SE Crater of Etna, November 16, 2006; photo by M. La Rosa (more pictures of the event can be found in Behncke et al., 2008). b - Llaima volcano on 18 January, 2008; photo Sernageomin, 2008. c - 1975 eruption of Pavlof volcano; USGS photo.

grained facies mantling the topography. The coarse-grained facies composed a single flow lobe (in some places two portions were evident) $1.2 \mathrm{~km}$ long, with thickness up to $5 \mathrm{~m}$ and volume about $4 \times 10^{5} \mathrm{~m}^{3}$. The lobe had steep, well-developed lateral levees indicating substantial yield strength of the material in the last moments of the flow motion. Deposition temperatures were moderate; wooden and plastic objects found on the upper surface of the deposit did not show any effects of heating (although some juvenile clasts were hot; in several places on the deposit surface temperatures about $200{ }^{\circ} \mathrm{C}$ were measured).
The coarse-grained facies was composed of bombs surrounded by poorly sorted lapilly-ash matrix (see Figs. 7 and 8 in Norini et al., 2009). The deposit was massive or with poorly developed reverse grading. Material of the facies was heterolithologic; abundant clasts of oxidized, weathered and hydrothermally altered rocks, derived from the SEC cone (the material that had been slumping to the cone's base prior to the 14:25 GMT explosions) were mixed with $41-49 \%$ of juvenile clasts. The bombsize juvenile clasts were represented by poorly-moderately vesiculated lava fragments that had cauliflower surface morphology.

The fine-grained facies had a volume of about $3 \times 10^{5} \mathrm{~m}^{3}$. It covered the area of about $2.3 \times 10^{5} \mathrm{~m}^{2}$; the deposit was up to $30 \mathrm{~cm}$ thick in its central zone and only a few mm thick near its margins. The facies is composed of reddish-brown fine- to coarse-grained ash with a minor proportion of lapilli. Content of non-juvenile material is higher than in the coarse-grained facies (70-90\% reported by Norini et al., 2009).

Surface morphologies of ash fractions from both facies were very variable ranging from well-vesiculated scoria to dense blocky particles. That is obviously due to the presence, along with poorly vesiculated juvenile material, of a significant percentage of very heterogenic material derived from the slid part of the SEC (composed of scoria and spatter).

The described deposit is akin to the deposits of dry volcanoclastic density currents and has characteristics transitional between block and ash flow and debris avalanche. The high concentration of accidental material $(>51 \%)$ and relatively low depositional temperatures make the coarse-grained facies different from the deposits of conventional pyroclastic flows (e.g. Fisher and Schmincke, 1984). Contrary, the absence of chaotic internal structure reflecting incomplete intermixing of the collapsed material, as well as lack of jigsaw fractures does not allow to classify the coarse-grained facies as a conventional debris avalanche deposit (e.g. Siebert, 1984). The characteristics of the fine-grained facies indicate that its material was elutriated by gas escaping from the main flow that deposited the coarse-grained facies. Furthermore, the significant volume of the finegrained facies suggests that the parental dry volcanoclastic density current was strongly gas-fluidized during its motion and was transported in a way more close to a pyroclastic flow (debris avalanches are poorly fluidized (Siebert, 1984) and lack equivalents of the fine-grained facies of the November 16 event).

In the case of the 29 March 2007 event, only the associated fallout deposit was studied (Andronico et al., 2008). Ash deposited on the snow surface adjacent to the lava flow consisted of both juvenile particles derived from the active lava and the abundant non-juvenile particles probably derived from the substrate of the lava flow. The distal fallout deposit from that event (sampled in locations around Etna) also showed a high percentage (13\%) of non-juvenile particles that differed it from the nearly entirely juvenile composition of tephras ejected from primary explosive vents in 2007.

\subsection{Discussion: mechanism of the explosions and PF formation at Etna}

The 16 and 24 November 2006 eruptive episodes were not unusually violent or voluminous, but they differed from anything documented in the recent history of Etna. The complexity of the events led to the discussion about their triggering mechanisms: did they originate from pure gravitational collapse (Norini et al., 2009), the opening of an eruptive fissure (Ferlito et al., 2009), or from rootless phreatomagmatic explosions (Behncke et al., 2008)?

As shown above, the resulting deposit had characteristics intermediate between deposits of debris avalanches and block-andash flows. Several lines of evidences demonstrate that purely gravitational (non-explosive) slope collapse as the sole process of generation of the described flow cannot be accepted. First of all, the scar formed in the SEC flank on 16 November was already almost fully developed by the time of the formation of the PF; the scar was formed by the preceding slow slumping and underwent no significant change 
after the PF formation. The onset of the PF was clearly linked to the vigorous explosions that occurred at the base of the SEC cone covered by the slumped material.

Juvenile clasts in the PF deposit were represented by poorly vesiculated fragments of the lava flow. They had cauliflower surface morphology indicating that those explosions were secondary, rootless and had phreatomagmatic origin. Predominance of hydrothermally altered material in the PF deposit allows to suggest that the explosions occurred when hydrothermal fluids contained in the slumping block of the SEC came into contact with lava intruding and covering the block. It also cannot be excluded that a lens of buried ice or snow was present in the foot of the SEC covered by the slumping material. That could induce an explosive process similar to lava/water interaction during the 1783-1784 Laki eruption in Iceland that formed multiple rootless cones or "pseudocraters" (Hamilton et al., 2010).

Despite the clearly explosive initiation of the PF on 16 November, the high percentage of cold non-juvenile material in the deposit allows to suggest that the mechanism proposed above to explain the origin of the PFs at Klyuchevskoy volcano can be applied here also. Explosive interaction between the hot lava and older material saturated with hydrothermal fluids may have been triggered by continuing deformations of the slumping block. Perhaps immediately before the explosions the sliding was activated by an increase of pore pressure inside the slumping block due to boiling of hydrothermal fluids heated up by hot lava intruding and covering the block. In general, the mechanism of fragmentation, which provided material for the PF, is to be sought in a combination of phreatomagmatic explosion and gravity sliding, although the latter was probably less important than at the Klyuchevskoy volcano due to the much flatter slope.

There is much less data for interpretation of the other two events that produced secondary explosions and PFs on 24 November 2006 and 29 March 2007, because they were less observed and the deposits were not studied. It is plausible that the mechanisms of the 24 November events were identical to those of the 16 November. Small secondary explosions which continued to occur in the area of the 24 November PF deposit might have been caused by the continuing interaction of blocks of hot lava and not completely intermixed domains of wet substrate.

In the case of the 29 March 2007 event, violent explosive interaction between lava and substrate occurred only when the lava flow had reached a steep slope, whereas only weak explosions occurred while the lava traveled over gently sloping terrain. Thus gravitational failure involving the active lava and causing its mixing with snow and wet/frozen substrate seems to have been an important factor leading to the PF-generating explosions. The 29 March 2007 event may have been most similar to the secondary explosions observed at Klyuchevskoy.

\subsection{Discussion: similar cases worldwide}

Searching in literature, published pictures of eruptions, Internet resources etc. allowed us to identify three more volcanoes (Llaima, Pavlof, and Hekla), where secondary rootless explosions or PF deposits similar to those described above have occurred during recent eruptions.

\subsubsection{Llaima}

Llaima volcano $(3421 \mathrm{~m})$, a glacier-clad basaltic volcano in the Araucania region of southern Chile, is one of the most active volcanoes of South America. Major eruptions occurred in 1945, 1956, 1994 and 2008-2009, and all produced lava flows that descended over snow- and ice-covered slopes, generating lahars (Naranjo and Moreno, 1991). The latest eruption from 1 January 2008 to April 2009 was characterized by a series of powerful fire-fountaining events. The paroxysms generated lava flows rapidly moving over and cutting into glacial ice and possibly further into underlying rocks on the steep upper slopes of the volcano. Minor activity between the main paroxysms included Strombolian activity and effusions of lava flows, both from the summit and from vents on the upper flanks of the volcano.

In January-February 2008 a series of explosive events that were variously described as "lateral" explosions accompanied by "flows of incandescent lava blocks and ash" or "pyroclastic flows" was observed on lava flows descending along the NE and E flanks (Sernageomin, 2008). A photograph of one of these events taken on 18 January shows a high vertical billowing ash-laden eruptive cloud originating from the upper quarter of the volcanic slope covered by sparse snow fields (Fig. 8b). From the base of the column a ground hugging cloud of PF is descending downslope. The lower part of the ash cloud above the PF is dark gray, but higher it becomes white due to condensation of steam. At the same time, the summit crater of the volcano showed no signs of explosive activity.

A major paroxysm with lava fountains, tephra emission, and lava flows descending down the volcano flanks covered with thick snow occurred on 3-6 April 2009. Photographs taken during this event (Sernageomin, 2009) show white steam and dense reddish-brown to gray vertical ash plumes as well as small PFs descending along one of the active lava flows cutting into a glacier. The clouds are clearly separated from the eruption column generated by the summit eruptive activity. The explosions and the PFs were accompanied by lahars carrying abundant ice fragments.

Although the results of investigations of the products of the explosions and the PDCs of Llaima have not been published yet, overall the similarity of the explosive events to the described explosions at Klyuchevskoy and Etna suggest that they had the same origin.

\subsubsection{Pavlof}

Pavlof (Alaska Peninsula) is a snow and ice-covered basaltic andesitic stratovolcano $2518 \mathrm{~m}$ high. It is the most frequently erupting volcano of the region; latest eruptions occurred in 1973-1975, 1986-1988, 19961997, and 2007 (Waythomas et al., 2008). The characteristic eruptive styles are moderate Strombolian (VEI 2-3) with lava fountaining and outpouring of spatter-fed lava flows. All recent eruptions of Pavlof have generated significant lahars.

A perspective air photo dated as 1973 shows the volcano with a small lava fountain from a vent near the summit, and a large billowing cloud developing over a whole length of lava flow streaming down the snowclad flank of the volcano. In its upper portion the cloud is dark brown but further downslope consists mainly of gray steam with some ash. On the AVO web site it is indicated that pyroclastic flow, surge or nuée ardente was observed during the 1973 eruption (Stone and Kienle, 1975). A similar photograph by the USGS is dated as 1975 (Fig. 8c). Pavlof reportedly erupted both in 1973 and 1975, although detailed descriptions of the events shown in the photographs are not available.

The large clouds visible in the both photographs are clearly detached from the eruptive plumes fed by the summit activity. The clouds resemble those produced by PF-generating explosions at the contact between lava and ice or moist rocks at Klyuchevskoy and Etna.

\subsubsection{Hekla}

One of the most active volcanoes in Iceland, Hekla (1491 m) has produced 18 eruptions since 1104 . In the past few decades it has been erupting about every 10 years, most recently in 2000 (Höskuldsson et al., 2007). During its historical activity, the volcano has erupted mostly basaltic andesites; lavas have strongly dominated over tephras.

The latest eruption in February 2000 consisted of initial short-lived subplinian stage (eruption cloud of $12 \mathrm{~km}$ high; $0.001 \mathrm{~km}^{3}$ of tephra) that was followed by 12 days of lava fountaining and outpouring of several lava flows from a $6.6 \mathrm{~km}$ long eruptive fissure. The basaltic andesite lava flows $\left(0.188 \mathrm{~km}^{3} ; 55.5 \% \mathrm{SiO}_{2}\right)$ descended over steep snow-clad slopes (Höskuldsson et al., 2007). 
The eruption also produced PFs whose emplacement was not directly observed, but the deposit was found and investigated a year after the eruption (Höskuldsson et al., 2007). Along the northern part of the 2000 eruptive fissure, several lobes of the PF deposit extended beyond the overlying lava flow. The deposit consisted of juvenile material (cauliflower bombs 10-30 cm across) and lithics (older lava and welded pyroclasts $5-10 \mathrm{~cm}$ across) in matrix of fine ash. On the southern flank of Hekla, three voluminous overlapping PF lobes were interfingerred with lava flows, indicating that effusion of lava preceded and followed deposition of the PFs. The largest PF lobe was $2 \mathrm{~m}$ thick with well-defined lateral margins and consisted of juvenile material (cauliflower and bread crust bombs $10-150 \mathrm{~cm}$ across) and lithics (dense lava fragments $2-20 \mathrm{~cm}$ across) in matrix of fine to coarse ash. The flow lobe was surrounded by a thin, 1-17 $\mathrm{m}$ wide apron of similar material interpreted as ash cloud surge deposit.

The 2000 PF deposits of Hekla demonstrate many similarities to the PF deposits produced by secondary phreatomagmatic explosions at Klyuchevskoy and Etna, including the presence of abundant cauliflower bombs (indicator of magma-water interaction), and a notable amount of non-juvenile clasts (indicator of involvement of the substrate). Höskuldsson et al. (2007) surmised that the PFs of Hekla originated from collapse of the eruption column as primary eruptive vents widened. But, given the lava flows of the 2000 eruption descended over steep slopes composed of frozen volcanoclastic material covered with snow and ice, we suggest that the PFs could have been produced as a result of secondary rootless phreatomagmatic explosions at the lava flows.

\subsection{Discussion summary}

The described secondary explosions and the resulting deposits at Klyuchevskoy and Etna show many common features and obviously have had similar origins. Summarizing these features we can deduce the driving forces of the explosions, as well as formulate the necessary conditions for them to occur.

The explosions occurred at actively advancing lava flows in places located far away from the primary volcanic vents. Thus the explosions were not associated with processes operating in the magma feeding systems, and can be termed as rootless or secondary. Juvenile material ejected by the explosions shows the characteristics typical for MFCI phreatomagmatic eruptions: (1) abundant fine-grained particles that are poorly vesicular and have blocky morphology with chip-off marks caused by thermal shock; (2) coarse clasts have either quenched, glassy outer surfaces dissected by multiple cracks or resemble cauliflower-type volcanic bombs similar to those ejected by Surtseyan eruptions.

In all the considered cases the explosions occurred at lava flows propagating over water-saturated substrate. In most cases it was frozen ice-saturated volcanoclastic material sometimes also covered by snow/ice fields. In fewer cases the substrate was composed of altered rocks saturated by hydrothermal fluids. No other sources of water existed in the location of the explosions. Thus we conclude that in the cases of the described phreatomagmatic explosions water contained in the substrate of the lava flows did actively participate. Extensive lahars accompanied many of the explosions, thus the substrate contained plenty of water far exceeding the volume necessary for the highly explosive fuel/coolant type interaction.

Another critical observation was that in nearly all the studied cases the explosions occurred on rather steep slopes. The same lavas (with the same physical properties) descending on gentle slopes over similar water-/ice-saturated substrate produced secondary explosions of much smaller scales that never generated PFs. We believe that gravitational sliding of a part of lava flow was the necessary element of the mechanism of the described explosions: it caused initial mechanical fragmentation and intensive intermixing of lava and water-saturated substrate that led to MFCI explosion. The sliding occurred due to several reasons such as gravitational loading by the growing lava field; mechanical weakening of the substrate caused by melting of the contained ice; growth of pore pressure in the substrate. The sliding also explains significant proportion of non-juvenile substrate-derived material in the products of the explosions. Sliding probably also released lithostatic pressure from pockets of overheated water and/or steam accumulated under the base of the lava flows that added energy to the explosions. Because of the importance of gravitational sliding in the origin of the described explosions we propose the term "landslide-induced secondary phreatomagmatic explosions" for this type of events.

The studied cases at Klyuchevskoy and Etna clearly demonstrate that secondary rootless phreatomagmatic explosions at lava flows can be very violent, heavily charged with pyroclastic material, and are able to generate rather significant PFs. The resulted PF deposits have characteristics that allow to distinguish them in old volcanoclastic sequences. They are characterized by mild depositional temperatures (no charcoal), contain significant (up to 50\%) proportions of substrate-derived non-juvenile material as well as poorly vesiculated juvenile material having signs of rapid quenching due to contact with external water. Obviously, depending on relative volumes of collapsed incandescent lava and water-saturated substrate should be a continuum of deposits of such events having different depositional temperatures and different proportions of non-juvenile clasts.

Searching of similar events at other volcanoes revealed that secondary explosions with generation of pyroclastic flows also repeatedly occurred at lava flows of Llaima, Pavlof, and Hekla. This indicates that such explosions represent a rather widespread natural phenomenon relevant in many volcanic settings worldwide.

\section{Conclusions}

The main results can be summarized as follows:

1. Powerful rootless phreatomagmatic explosions generating blockand-ash flows can occur at lava flows of basic composition propagating over steep, water-/ice- saturated slopes.

2. Mechanisms of the explosions include the following rapid succession of events: gravitational sliding of a part of active lava flow together with water-saturated substrate, their initial fragmentation, intermixing and explosive interaction of "fuel/coolant" type (proposed term "landslide-induced secondary phreatomagmatic explosions"). The produced gas/pyroclast mixture is not buoyant and thus forms pyroclastic flow. Excess of water in the sliding substrate forms a lahar.

3. The landslide-induced secondary phreatomagmatic explosions appear to be common at snow/ice-clad basaltic stratovolcanoes but can also occur at water-saturated volcanic slopes (including those affected by hydrothermal alteration), and thus the related hazard is present in many volcanic areas.

Supplementary materials related to this article can be found online at doi:10.1016/j.jvolgeores.2011.01.004.

\section{Acknowledgements}

$\mathrm{AB}$ and $\mathrm{MB}$ have collected data on the secondary explosions of Klyuchevskoy volcano while working at Kamchatka Volcano Observatory in Klyuchi (Academy of Sciences of the USSR) during many years. BB thanks R. Campion, the Etnean mountain guides, and N. Mazzaglia for furnishing precious information on some of the events described in this paper, and G. Norini for the additional data on componentry in the 16 November 2006 deposits at Etna. Karoly Nemeth and anonymous reviewer contributed to the clarity of this manuscript greatly. This is an Earth Observatory of Singapore contribution number 15. 


\section{References}

Andronico, D., Cristaldi, D., Scollo, S., 2008. The 4-5 September 2007 lava fountain at SouthEast Crater of Mt Etna, Italy. Journal of Volcanology and Geothermal Research 173, $325-328$.

Behncke, B., 2009. Hazards from pyroclastic density currents at Mt. Etna (Italy). Journal of Volcanology and Geothermal Research 18, 148-160.

Behncke, B., Neri, M., Pecora, E., Zanon, V., 2006. The exceptional activity and growth of the Southeast Crater, Mount Etna (Italy), between 1996 and 2001. Bulletin of Volcanology 69, 149-173.

Behncke, B., Calvari, S., Giammanco, S., Neri, M., Pinkerton, H., 2008. Pyroclastic density currents resulting from the interaction of basaltic magma with hydrothermaly altered rocks: an example from the 2006 summit eruptions of Mount Etna, Italy. Bulletin of Volcanology 70, 1249-1268.

Belousov, A., 1990. Phreatic explosion at Klyuchevskoy volcano at December 2, 1985. Questions of Geography of Kamchatka 10, 108-112 (in Russian).

Belousov, A.B., 1996. Block and Ash Pyroclastic Flows of Basaltic Composition Generated by Secondary Phreatomagmatic Explosions on Lava Flows - New Type of Volcanic Hazard Demonstrated by 1994 Eruption of Kluchevskoy Volcano, Kamchatka. Pan Pacific Hazard Conference, Vancouver, 29.

Belousov, A., Belousova, M., 2001. Eruptive process, effects and deposits of the 1996 and ancient basaltic phreatomagmatic eruptions in Karymskoye lake, Kamchatka, Russia. In: White, J.D., Riggs, N.R. (Eds.), Volcanoclastic Sedimentation in Lacustrine Settings IAS Special Number 30, pp. 35-60.

Braitseva, O.A., Melekestsev, I.V., Ponomareva, V.V., Sulerzhitsky, L.D., 1995. The ages of calderas, large explosive craters and active volcanoes in the Kuril-Kamchatka region, Russia. Bulletin of Volcanology 57, 383-402.

Büttner, R., Dellino, P., Zimanowski, B., 1999. Identifying magma-water interaction from the surface features of ash particles. Nature 401, 688-690.

Büttner, R., Dellino, P., La Volpe, L., Lorenz, V., Zimanowski, B., 2002. Thermohydraulic explosions in phreatomagmatic eruptions as evidenced by the comparison between pyroclasts and products from molten fuel coolant interaction experiments. Journal of Geophysical Research 107 (2277) 14 pp.

Calvari, S., Pinkerton, H., 2002. Instabilities in the summit region of Mount Etna during the 1999 eruption. Bulletin of Volcanology 63, 526-535.

Chester, D.K., Duncan, A.M., Guest, J.E., Kilburn, C.R.J. (Eds.), 1985. Mount Etna: the Anatomy of a Volcano. Chapman Hall, London. $404 \mathrm{pp}$.

Dvigalo, V.N., Melekestsev, I.V., 2000. Recent large-scale downfalls on the cone of Klyuchevskoi volcano: a revision of the consequences of the events of 1944-1945 1984-1985 and 1994. Volcanology and Seismology 22, 1-23.

Fedotov, S.A., Masurenkov, Y.P. (Eds.), 1991. Active Volcanoes of Kamchatka. Moscow, Nauka.

Ferlito, C., Viccaro, M., Nicotra, E., Cristofolini, R., 2009. Comment on "Complex magma dynamics at Mount Etna revealed by seismic, thermal, and volcanological data" by B. Behncke, S. Falsaperla, and E. Pecora. Journal of Geophysical Research 114, B12204.

Fisher, R.V., Schmincke, H.U., 1984. Pyroclastic Rocks. Springer-Verlag, New York. 472 pp.

Hamilton, C., Fagent, S., Thordarson, T., 2010. Explosive lava-water interactions I: architecture and emplacement chronology of volcanic rootless cone groups in the 1783-1784 Laki lava flow, Iceland. Bulletin of Volcanology 72, 449-467.

Heiken, G., Wohletz, K., 1985. Volcanic Ash. University of California Press, Berkley.

Höskuldsson, A., Óskarsson, N., Pedersen, R., Grönvold, K., Vogfjörð,, K., Ólafsdóttir, R., 2007. The millennium eruption of Hekla in February 2000. Bulletin of Volcanology 70, 169-182.

Houghton, B., Wilson, C., 1989. A vesicularity index for pyroclastic deposits. Bulletin of Volcanology 51, 451-462.

Kokelaar, P., 1983. The mechanism of Surtseyan volcanism. Journal of Geological Society of London 140, 939-944.

Lockwood, J.P., Hazlett, R.P., 2010. Volcanoes: Global Perspectives. Willey-Blackwell. 539 pp.
Manen, S.M., Dehn, J., 2009. Satellite remote sensing of thermal activity at Bezymianny and Kliuchevskoi from 1993 to 1998. Geology 37, 983-986.

Mattox, T.N., Mangan, M.T., 1997. Littoral hydrovolcanic explosions: a case study of lava-seawater interaction at Kilauea volcano. Journal of Volcanology and Geothermal Research 75, 1-17.

Morrissey, M.M., Thordarson, T., 1991. Origins and occurrences of pseudocrater fields in Southern Iceland. Eos Transactions AGU 72, 556.

Morrissey, M., Zimanowski, B., Wohletz, K., Büttner, R., 2000. Phreatomagmatic fragmentation. In: Sigurdsson, H., Houghton, B.F., et al. (Eds.), Encyclopedia of Volcanoes. Academic Press, New York, pp. 431-445.

Muravyev, Ya.D., 1985. Snow accumulations of mountain regions of Kamchatka. Questions of Geography of Kamchatka, p. 9 (in Russian).

Naranjo, J.A., Moreno, H., 1991. Actividad explosiva postglacial en el volcan Llaima, Andes del Sur ( $38^{\circ} 45^{\prime}$ S). Revista Geologica de Chile 18, 69-80.

Norini, G., De Beni, E. Andronico, D., Polacci, M., Burton, M., Zucca, F, 2009. The 16 November 2006 flank collapse of South-East Crater at Mount Etna, Italy: study of the deposit and hazard assessment. Journal of Geophysical Research 114 B02204.1-B02204.19.

Ozerov, A.Y., 2000. The evolution of high-alumina basalts of the Klyuchevskoy volcano, Kamchatka, Russia, based on microprobe analyses of mineral inclusions. Journal of Volcanology and Geothermal Research 95, 65-79.

Ozerov, A.Yu., Karpov, G.A., Droznin, V.A., Dvigalo, V.N., Demyanchuk, Yu.V., Ivanov, V.V. Belousov, A.B., Firstov, P.P., Gavrilov, V.A., Yashchuk, V.V., Okrugina, A.M., 1997. Klyuchevskoy volcano eruption of September 7-October 2, 1994, Kamchatka. Volcanology and Seismology 18, 501-516.

Piip, B.I., 1956. Klyuchevskaya sopka and its eruptions in 1944-1945 and in the past Proceedings of Volcanological Laboratory 11, 1-311 (in Russian).

Sernageomin, 2008. Análisis de la actividad del Volcán Llaima (on-line).

Sernageomin, 2009. Análisis de la actividad del Volcán Llaima (on-line).

Siebert, L., 1984. Large volcanic debris avalanches: characteristics of source areas, deposits, and associated eruptions. Journal of Volcanology and Geothermal Research 22, 163-197.

Stone, D.B., Kienle, J., 1975. Pavlov. Annual Report of the World Volcanic Eruptions in 1973 with Supplements to the Previous Issues: Bulletin of Volcanic Eruptions, 13, p. 50.

Tanguy, J.C., Condomines, M., Kieffer, G., 1997. Evolution of the Mount Etna magma: constraints on the present feeding system and eruptive mechanism. Journal of Volcanology and Geothermal research 75, 221-250.

Vinogradov, V.N., Muravyev, Ya.D., 1985. Lava-ice interaction during 1983 eruption of Klyuchevskoy volcano. Volcanology and Seismology 1, 29-46.

Vinogradov, V.N., Muravyev, Ya.D, Nikitina, I.M., Solomatin, A.N., 1987. About mechanism of formation of phreatic eruptions connected with magma-ice interaction. Volcanology and Seismology 1, 56-61.

Waythomas, C.F., Prejean, S.G., McNutt, S.R., 2008. Alaska's Pavlof Volcano ends 11-year repose. Eos Transactions AGU 89.

White, J.D.L., Houghton, B., 2000. Surtseyan and related phreatomagmatic eruptions. In: Sigurdsson, H., Houghton, B.F., et al. (Eds.), Encyclopedia of Volcanoes. Academic Press, pp. 495-511.

Wohletz, K.H., 1983. Mechanism of hydrovolcanic pyroclast formation: grain size, SE microscopy, experimental studies. Journal of Volcanology and Geothermal Research 17, 31-63.

Zharinov, N.A., Zhdanova, E.Yu., Belousov, A.B., Belousova, M.G., Ivanov, A.P., Malyshev, A.I., Khanzutin, V.P., 1990. Activity of North Kamchatka volcanoes in 1985. Volcanology and Seismology 10, 331-346.

Zimanowski, B., 1998. Phreatomagmatic explosions. In: Freundt, A., Rosi, M. (Eds.), From Magma to Tephra. Elsevier, Amsterdam, pp. 25-54.

Zimanowski, B., Wohletz, K.H., 2000. Physics of phreatomagmatism-1. Terra Nostra 6 515-523. 